\title{
Article \\ Effect of Harvest Date on Mango (Mangifera indica L. Cultivar Osteen) Fruit's Qualitative Development, Shelf Life and Consumer Acceptance
}

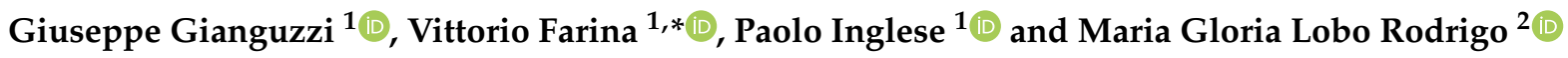 \\ 1 Department of Agricultural, Food and Forest Sciences, Università Degli Studi di Palermo, \\ 90128 Palermo, Italy; giuseppe.gianguzzi@unipa.it (G.G.); paolo.inglese@unipa.it (P.I.) \\ 2 Producción Vegetal en Zonas Tropicales y Subtropicales, Instituto Canario de Investigaciones Agrarias, \\ Carretera del Boquerón s/n, Valle de Guerra, 38270 San Cristóbal de La Laguna, Tenerife, Spain; globo@icia.es \\ * Correspondence: vittorio.farina@unipa.it; Tel.: +39-091-23896090
}

check for updates

Citation: Gianguzzi, G.; Farina, V.; Inglese, P.; Rodrigo, M.G.L. Effect of Harvest Date on Mango (Mangifera indica L. Cultivar Osteen) Fruit's Qualitative Development, Shelf Life and Consumer Acceptance. Agronomy 2021, 11, 811. https://doi.org/ 10.3390/agronomy11040811

Academic Editors: Vasileios Ziogas and Konstantinos Papoutsis

Received: 28 March 2021

Accepted: 16 April 2021

Published: 20 April 2021

Publisher's Note: MDPI stays neutral with regard to jurisdictional claims in published maps and institutional affiliations.

Copyright: (c) 2021 by the authors. Licensee MDPI, Basel, Switzerland. This article is an open access article distributed under the terms and conditions of the Creative Commons Attribution (CC BY) license (https:/ / creativecommons.org/licenses/by/ $4.0 /)$.

\begin{abstract}
The qualitative characteristics of mango fruits change throughout their development process and are also influenced by their duration. Harvesting at different times after the fruit set affects external and internal quality and the post-harvest behavior and management possibilities of the fruits. The objective of this study was to assess the evolution of the most important physicochemical and organoleptic parameters of cv. Osteen fruits concern the length of their stay on the plant and also to their post-harvest management. For this reason, fruits were harvested progressively in ten pickings. The study showed that mango fruits that are kept on the tree reach the best quality traits, corresponding to their physiological maturation. The length of the storage period needed to reach the consumption point varies greatly according to the harvesting moment and to the different environmental parameters, which also affect the organoleptic and physicochemical quality of the fruits. The number of days after full flowering were confirmed to be the primary information to consider when planning harvest with commercial use of the fruit, but interesting indications can be acquired through the definition of non-destructive (hardness, color) or destructive (dry matter) parameters. The data collected help improve mango fruit's post-harvest management practices, to provide a product with constant quality and homogeneity to the consumer.
\end{abstract}

Keywords: Mangifera indica; physicochemical analyses; sensory profile; consumption point

\section{Introduction}

The quality parameters of mango (Mangifera indica L.) fruits change daily. Being a climacteric fruit, mango is characterized by an increase of its transpiration activity after its physiological maturity stage; this is due to a process triggered by ethylene gas [1], during which the overall quality of the fruit changes substantially [2].

Mango fruits are usually harvested when they are still green and not physiologically ripe; they continue their ripening process during transportation and storage [3]. During this period, which can span over different times according to the storage methods, the fruits reach the optimal characteristics for their consumption [2,4-7].

Changes in the environmental conditions that fruits experience during their growth and storage can influence the final quality [8]. These changes happen during the ripening process and involve the variation in total soluble solids (TSS) content, $\mathrm{pH}$ value, carotenoid content and sugar/acid ratio [9-11]. Thus, fruit ripening on the tree and fruit ripening after harvesting reach different quality levels in a cultivar-dependent manner [12]: quality characteristics change completely depending on the time of harvesting. Therefore, it is crucial to identify the most appropriate harvesting time. As of today, there is no univocal criterion that can be used to correctly detect the ripeness degree of the fruit-based on its external aspect, and the non-destructive indices that are currently used during and after 
the harvest show a low accuracy [13,14]. Such destructive indices, in fact, proved to be not representative because of the management and cultivation variability among the various orchards [15]. Among the widely used criteria for determining the mango fruit ripeness, the most sensible refers to the number of days since full flowering [16]. This, however, must be adjusted according to the productive destination and the desired characteristics the fruit must acquire [17]. The number of days required also varies depending on the geographical region and microclimatic growing conditions of the trees [2]. This can result in production batches that are heterogeneous in terms of physicochemical parameters, making the post-harvest management of the fruits more complicated $[2,6,7,18]$.

The fruits collected early do not ripen properly and can show characteristics that make them unsuitable for consumption (abnormal color, low TSS content). On the other hand, a late harvest can determine an uneven ripening and reduce the sugar/acid ratio $[19,20]$.

The fundamental parameter regarding the ripeness is the TSS content, which has a strong influence on the consumers' appreciation of the product [21]. Research conducted by Makani [22] showed that cv. Tommy Atkins fruits with a high TSS content (above $13.5^{\circ}$ Brix), were appreciated by most of the consumers, while those with a low TSS content (below $12{ }^{\circ}$ Brix) were appreciated only by a small percentage. It is essential to evaluate if TSS and other chemical parameters are correlated with the dimension, shape, color and aroma of the fruits and if it is possible to detect them precisely to use them as harvest indices.

The goal of this study was to assess the evolution of the most important physicochemical parameters of $\mathrm{cv}$. Osteen fruits during their on-tree development and ripening process, to understand how the number of days between full flowering and harvest affects the physicochemical quality and shelf-life of the product. We also tried to define the actual influence of the harvesting time on the organoleptic quality of the fruits at consumption, considering the differences in their post-harvest management.

\section{Materials and Methods}

\subsection{Plant Material and Experimental Site}

The trial was carried out in an experimental orchard of the Instituto Canario de Investigaciones Agrarias (ICIA), called Cueva del Polvo, in the island of Tenerife (Canary Island, Spain-28 $18^{\prime} 4200^{\prime \prime} \mathrm{N} ; 16^{\circ} 50^{\prime} 0100^{\prime \prime} \mathrm{W}$ ). The trial was conducted on 15 -year-old cv. Osteen mango trees, grafted onto Gomera 1 rootstocks and trained to a vase shape, with a plantation frame of $5 \times 6 \mathrm{~m}$, and cultivated following the usual cultural practices. Osteen is a mango variety native of Florida and one of the most cultivated in Europe. The average daily temperature in the field, measured by a thermopluviometric station, was $21^{\circ} \mathrm{C}$, with an average daily minimum of $18{ }^{\circ} \mathrm{C}$ and an average daily maximum of $25^{\circ} \mathrm{C}$. The relative humidity (RH) average was $70 \%$ and $155 \mathrm{~mm}$ annual precipitation. Based on these data and according to the Koppen classification [23], the climate of the area can be defined as "tropical dry", or according to the Papadakis classification [24] as "tropical warm" [25].

\subsection{Experimental Design}

The beginning of the flowering of the mango trees taken into consideration in the year of the study (2018) happened between March and April. Full flowering was determined according to the $\mathrm{BBCH}$ scale for mango set up by Hernández Delgado et al. [26], where it corresponds to stage 615, when the number of open flowers in the panicle is higher than $50 \%$. The length, width, base diameter, and a number of flowers were measured in 10 fully formed flower panicles, to identify stage 615 on the $\mathrm{BBCH}$ scale.

The fruit development monitoring was carried out weekly on 32 fruits from two different trees ( 16 fruits per tree -4 fruits in each orientation-N, S, E, W). In particular, longitudinal (LD) and transverse major (TD1) and minor (TD2) diameters were measured, to define the morphological development during the period taken into consideration-from April to August. The two transverse diameters were measured to follow the evolution of the oblong shape of the cv. Osteen fruits. The diameter measuring began after the fruit set 
when the fruits had a longitudinal diameter of at least $10 \mathrm{~mm}$. The fruits were harvested progressively: the first day of harvesting - 105 days after full flowering-was established based on the fruit growth rate, when this was $<1 \%$. Then, 18 fruits at the same degree of ripening were collected every week, until day 168 from full flowering; these were selected according to their dimensions, good quality, and absence of damages or alterations, for a total amount of ca. 200 fruits. All the fruits were analyzed for their quality parameters. These analyses were carried out at the Tropical Horticulture Laboratory of the ICIA facility. In particular, after each weekly harvest, 6 of the 18 collected fruits were analyzed on the same day. The remaining 12 fruits were stored at the fixed temperature of $20{ }^{\circ} \mathrm{C}$ and $70 \%$ Relative Humidity until they reached a hardness value between 50-60 Durofel: then, 6 of the fruits underwent the same physicochemical analyses and the other 6 were used, on the same day, to conduct a panel test to assess the organoleptic characteristics of the fruits concerning the harvest date.

\subsection{Physicochemical and Color Analyses}

The analysis included the morphological characterization of the fruits: the weight $(\mathrm{g})$, which was measured using a digital scale with a precision of two places of two decimal units (Gibertini, Italy); the measurement of the transverse and longitudinal diameters ("1" and "2"), was performed using a digital caliper TR53307 (Turoni, Forli, Italy).

A CIELAB colorimetry system was used to define the color, using a Minolta CR-300 Chroma Meter (Konica Minolta, Tokyo, Japan) which recorded the spectrum of reflected light and converted it into a set of color coordinates ( $\mathrm{L}, \mathrm{a}^{*}$ and $\mathrm{b}^{*}$ values). A Minolta standard white plate was used to standardize the instrument [1]. Color measurements were performed at three points in the equatorial region of the mango peel and pulp.

The Dry Matter content of the fruits was measured removing a portion of $27 \mathrm{~mm}$ width and $10 \mathrm{~mm}$ depth of the fruit without its peel: the dry matter was then determined as the difference between the weight of the fresh sample (ranging between 5 and $10 \mathrm{~g}$ ) and the final weight of the sample after being kept for 7 days in an oven at $60^{\circ} \mathrm{C}$. The final weight is the value that remains constant after at least three repeated weightings of the sample.

Peel and pulp firmness were recorded with a penetrometer with an $8 \mathrm{~mm}$ diameter round probe for the pulp and a flat-ended probe for the peel (Turoni, Forli, Italy). The values obtained were rescaled according to the Hedonic scale for comparison purposes [26]: 10-8 meant firm, 8-6 slightly soft, 6-4 soft, 4-2 were over soft [3].

The hardness measurements were carried out in a rapid non-destructive way, using a Durofel (CTIFL Copa Technologie, Saint Etienne du Gres, France) dynamometer with a bolt of $3 \mathrm{~mm}$ diameter $\left(0.10 \mathrm{~cm}^{2}\right)$. This test measures the elasticity in the outer part of the fruit pulp without penetrating the fruit peel. The Durofel firmness tester was used to determine consumption points before applying destructive measures [27]. Hardness was calculated as the mean of the 3 measurements for each fruit sample and expressed on a scale from 1 (soft) to 100 (firm). Based on judgments by trained panels and consumers, consumption points corresponded to a firmness threshold of 50-60 Durofel unit.

\subsection{Sensory Analyses}

The sensory analyses were carried out by a semi-trained panel of 20 people [28] who evaluated the color of the peel and pulp, the presence of fibers, the aroma, the sweetness and the flavor, assigning qualitative and quantitative values. The judges evaluated the samples on a discontinuous scale, attributing to each descriptor a score ranging from " 1 " (absence of sensation) to "10" (maximum intensity of the descriptor). The fruits were evaluated when they reached the consumption point, after a period of storage at $20 \pm 1{ }^{\circ} \mathrm{C}$ and $70 \%$ R.H. At each panel session, each judge was supplied pieces from at least three different fruits. Among the judges the order of presentation of the fruit was randomized and water was used to rinse the mouth between each tasting [28]. 


\subsection{Data Analyses}

Data analysis was carried out using XLSTAT software (Addinsoft). Grubbs' test was applied to detect outliers in the data set. The physicochemical and sensory data were tested for differences between the harvest date using the one-way analysis of variance (ANOVA; general linear model). The differences between harvest date were tested with Tukey's high significance difference (HSD) test at the 0.05 significant level.

\section{Results and Discussions}

The observed mango trees reached full flowering on the week between 26-31 March 2018, when all the selected inflorescences were in the same phenological stage. The flower count showed that the average of their number per panicle was 1.543, the average length of the panicle was $25.51 \mathrm{~cm}$, the average width was 21.05 and the average basal diameter of $5.84 \mathrm{~mm}$. Each panicle was carrying an average of 33.32 secondary branches.

A sigmoidal-type growth was highlighted as fruits diameters (longitudinal and transverse) were monitored (Figure 1). At the beginning of monitoring (during the first 50 days after full flowering) a relevant flower drop was noticed and, later, the small fruits dropped even more intensively (more than $98 \%$ of the small set fruits fell from the panicles) [29]. After this phase, each panicle was carrying 4 or 5 fruits until day 90 from full flowering; however, at the end of development the average number of fruits per panicle was between 2 and 3. Fruit diameters increased rapidly until about 80 days after full flowering and then slowed down over time, until the fruit was fully developed, following the single sigmoidal pattern that is typical for the growth of mango fruits [30]. The fruits reached their final dimension (phenological stage 800 [25]) after approximately 100 days from full flowering; however, the weight of the fruits continued its increase in the whole period under consideration.

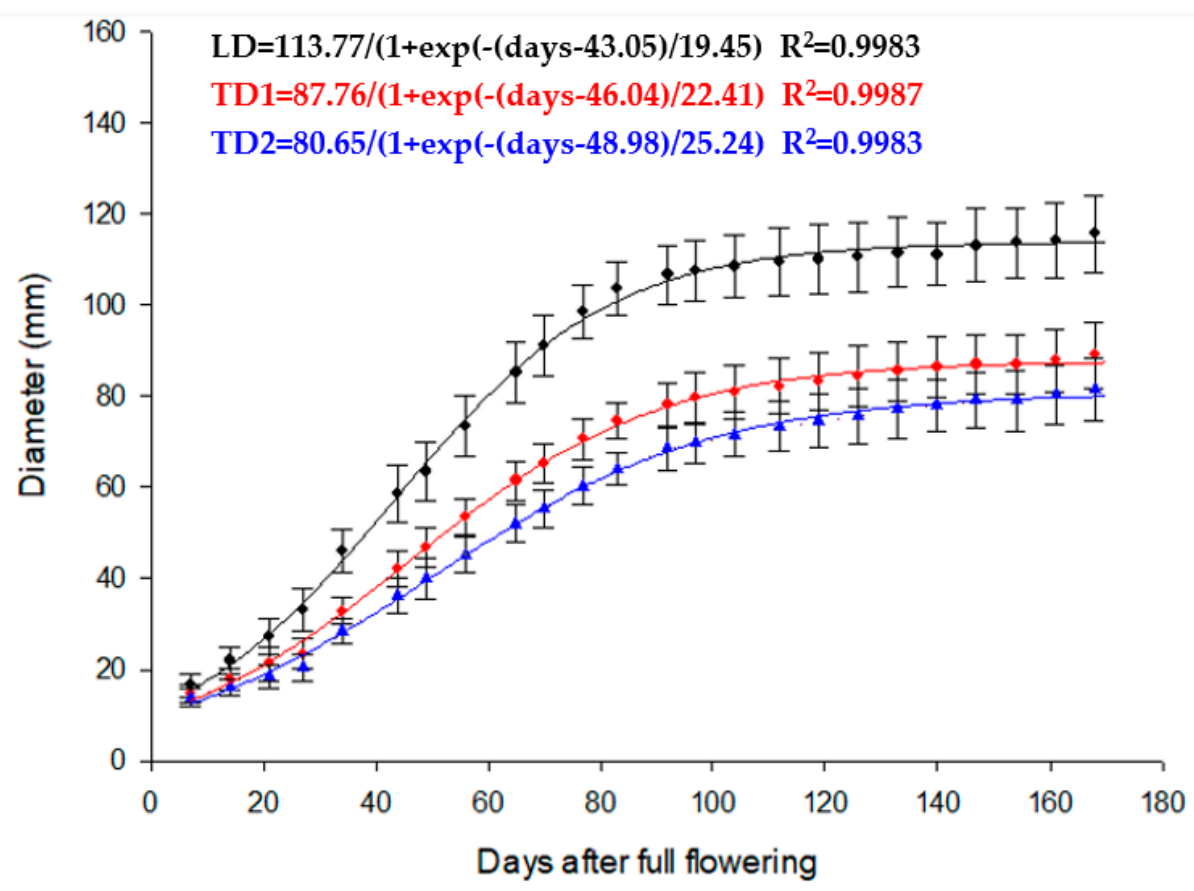

Figure 1. Time course of the diameters of the selected fruits (LD—Longitudinal Diameter-in black, TD1-Major Transversal Diameter-in red, TD2-Minor Transverse Diameter-in blue).

The observed mango trees reached full flowering on the week between 26-31 March 2018, when all the selected inflorescences were in the same phenological stage. The flower count showed that the average of their number per panicle was 1.543, the average length of the panicle was $25.51 \mathrm{~cm}$, the average width was 21.05 and the average basal diameter of $5.84 \mathrm{~mm}$. Each panicle was carrying an average of 33.32 secondary branches. The hardness 
of the fruit at harvest did not vary significantly between the harvesting date $\left(80-90^{\circ}\right.$ Durofel) in the samples left on the tree during the whole growth period (Table 1). Nevertheless, a slight decrease was observed at the consumption point in those fruits harvested later on, probably due to major peel dehydration. The loss of hardness of peel is due to the action of enzymes that alter the structure and composition of the cell walls [31], with partial or total solubilization of the polysaccharides, hydrolysis of starch and other polysaccharides [32]. Peel firmness values at the consumption point are inversely related to the time of storage at room temperature.

Table 1. Physicochemical parameters of Osteen mango (mean $\pm \mathrm{SD}, n=3$ ) at harvest date (days after full flowering).

\begin{tabular}{|c|c|c|c|c|c|c|c|c|}
\hline \multirow{2}{*}{$\begin{array}{c}\begin{array}{c}\text { Harvest } \\
\text { Date }\end{array} \\
105\end{array}$} & \multicolumn{2}{|c|}{$\begin{array}{l}\text { Hardness } \\
\left({ }^{\circ} \text { Durofel) }\right.\end{array}$} & \multicolumn{2}{|c|}{$\begin{array}{l}\text { Peel Firmness } \\
\left(\mathrm{kg} / \mathrm{cm}^{2}\right)\end{array}$} & \multicolumn{3}{|c|}{$\begin{array}{l}\text { Pulp Firmness } \\
\left(\mathrm{kg} / \mathrm{cm}^{2}\right)\end{array}$} & Dry Matter (\%) \\
\hline & $86.56 \pm 0.97$ & ns & $11.82 \pm 0.34$ & $\mathrm{a}$ & 8.44 & \pm 0.31 & $\mathrm{a}$ & $11.71 \pm 0.53 \mathrm{e}$ \\
\hline 112 & $85.67 \pm 0.84$ & ns & $11.31 \pm 0.40$ & $\mathrm{a}$ & 8.03 & \pm 0.23 & $\mathrm{a}$ & $12.79 \pm 0.46 \mathrm{de}$ \\
\hline 119 & $84.67 \pm 1.18$ & ns & $10.50 \pm 0.34$ & $a b$ & 7.88 & \pm 0.23 & $\mathrm{a}$ & $13.55 \pm 0.46 \mathrm{~d}$ \\
\hline 126 & $83.06 \pm 1.18$ & ns & $9.60 \pm 0.34$ & $\mathrm{~b}$ & 7.40 & \pm 0.40 & $\mathrm{ab}$ & $13.96 \pm 0.46 \mathrm{~d}$ \\
\hline 133 & $85.22 \pm 0.75$ & ns & $9.36 \pm 0.31$ & $\mathrm{~b}$ & 6.15 & \pm 0.21 & $\mathrm{~b}$ & $15.09 \pm 0.41 \mathrm{~cd}$ \\
\hline 140 & $85.64 \pm 0.84$ & ns & $8.64 \pm 0.35$ & $\mathrm{~b}$ & 6.16 & \pm 0.23 & $\mathrm{~b}$ & $16.03 \pm 0.48 \mathrm{c}$ \\
\hline 147 & $84.83 \pm 0.84$ & ns & $7.97 \pm 0.34$ & $\mathrm{bc}$ & 5.61 & \pm 0.23 & $c$ & $16.34 \pm 0.46 \mathrm{c}$ \\
\hline 154 & $81.25 \pm 0.84$ & ns & $9.32 \pm 0.35$ & $\mathrm{~b}$ & 5.60 & \pm 0.23 & $c$ & $16.11 \pm 0.46 \mathrm{bc}$ \\
\hline 161 & $82.17 \pm 1.02$ & ns & $7.64 \pm 0.40$ & $\mathrm{c}$ & 4.89 & \pm 0.31 & $\mathrm{~cd}$ & $17.34 \pm 0.46 \mathrm{~b}$ \\
\hline 168 & $82.91 \pm 0.84$ & ns & $8.14 \pm 0.45$ & $\mathrm{bc}$ & 3.80 & \pm 0.23 & $\mathrm{~d}$ & $19.01 \pm 0.50 \mathrm{a}$ \\
\hline
\end{tabular}

The values followed by different letters in the same column indicate significant differences (Tukey test, $p<0.05$; ns $=$ not significant).

At the consumption point, the fruits showed firmness values below $1.5 \mathrm{~kg} / \mathrm{cm}^{2}$ (Table 2) [33]. The change in this parameter after the fruit was harvested is of utmost importance to define ripening protocols for the fruits themselves, to obtain ready-to-eat products, which have an increasingly stronger demand on the market [34].

Table 2. Physicochemical parameters of Osteen mango (mean $\pm \mathrm{SD}, n=3$ ) at consumption point after period of storage at $20{ }^{\circ} \mathrm{C}$ and $70 \% \mathrm{RH}$ (harvest date + shelf life).

\begin{tabular}{cccccccccc}
\hline Harvest Date + Storage Period (days) & \multicolumn{2}{c}{$\begin{array}{c}\text { Hardness } \\
\left({ }^{\circ} \text { Durofel) }\right.\end{array}$} & $\begin{array}{c}\text { Peel Firmness } \\
\left(\mathbf{k g} / \mathbf{c m}^{2}\right)\end{array}$ & $\begin{array}{c}\text { Pulp Firmness } \\
\left(\mathbf{k g} / \mathbf{c m}^{\mathbf{2}}\right)\end{array}$ & Dry Matter (\%) \\
\hline $105+28$ & $54.90 \pm 1.60$ & $\mathrm{~ns}$ & $1.61 \pm 0.16$ & $\mathrm{~ns}$ & $0.60 \pm 0.05$ & $\mathrm{~ns}$ & $10.38 \pm 0.55$ & $\mathrm{e}$ \\
$112+27$ & $53.47 \pm 2.27$ & $\mathrm{~ns}$ & $1.30 \pm 0.23$ & $\mathrm{~ns}$ & $0.62 \pm 0.07$ & $\mathrm{~ns}$ & $11.80 \pm 0.77$ & $\mathrm{~d}$ \\
$119+21$ & $53.73 \pm 2.27$ & $\mathrm{~ns}$ & $1.49 \pm 0.23$ & $\mathrm{~ns}$ & $0.58 \pm 0.07$ & $\mathrm{~ns}$ & $13.24 \pm 0.77$ & $\mathrm{c}$ \\
$126+20$ & $57.53 \pm 2.27$ & $\mathrm{~ns}$ & $1.87 \pm 0.23$ & $\mathrm{~ns}$ & $0.65 \pm 0.07$ & $\mathrm{~ns}$ & $14.17 \pm 0.77$ & $\mathrm{bc}$ \\
$133+20$ & $55.57 \pm 1.60$ & $\mathrm{~ns}$ & $1.52 \pm 0.18$ & $\mathrm{~ns}$ & $0.73 \pm 0.05$ & $\mathrm{~ns}$ & $15.43 \pm 0.60$ & $\mathrm{~b}$ \\
$14+16$ & $56.63 \pm 1.60$ & $\mathrm{~ns}$ & $2.33 \pm 0.21$ & $\mathrm{~ns}$ & $0.92 \pm 0.05$ & $\mathrm{~ns}$ & $16.19 \pm 0.55$ & $\mathrm{~b}$ \\
$14+16$ & $58.33 \pm 2.07$ & $\mathrm{~ns}$ & $1.99 \pm 0.28$ & $\mathrm{~ns}$ & $0.98 \pm 0.07$ & $\mathrm{~ns}$ & $15.39 \pm 0.77$ & $\mathrm{~b}$ \\
$154+15$ & $57.79 \pm 1.79$ & $\mathrm{~ns}$ & $2.03 \pm 0.21$ & $\mathrm{~ns}$ & $0.65 \pm 0.05$ & $\mathrm{~ns}$ & $17.75 \pm 0.60$ & $\mathrm{ab}$ \\
$161+14$ & $59.78 \pm 2.07$ & $\mathrm{~ns}$ & $2.53 \pm 0.25$ & $\mathrm{~ns}$ & $0.50 \pm 0.07$ & $\mathrm{~ns}$ & $16.50 \pm 0.77$ & $\mathrm{~b}$ \\
$168+12$ & $58.89 \pm 2.07$ & $\mathrm{~ns}$ & $2.13 \pm 0.28$ & $\mathrm{~ns}$ & $0.50 \pm 0.07$ & $\mathrm{~ns}$ & $19.44 \pm 0.77$ & $\mathrm{a}$ \\
\hline
\end{tabular}

The values followed by different letters in the same column indicate significant differences (Tukey test, $p<0.05$; ns = not significant).

Dry Matter (DM) is a very important quality index, as it is linked to the carbohydrate content in the fruit, which are the compounds that have the biggest influence on the typical taste of mango [35]. The Dry Matter content of the fruits can be monitored and used as an indicator of the appropriate harvest moment for mango [36], which generally correspond to values around 15\% DM content [37]. Various authors [38,39] found a better overall sensory quality in mango fruits with smaller water content. In our study, the Dry Matter content of the fruits varied significantly from values of $11.5 \%$ to $21 \%$ with the harvesting 
moment. The changes in all the mentioned parameters are the key factor to enact the best post-harvest practices and estimate the final quality of the fruit [40].

Color is the parameter whose change is the most noticeable during the development of the fruit both on the plant and after the harvest and is often indicated as a fundamental criterion for consumer's choice [41]. However, it is not an appropriate index of mango fruits' ripeness, because color differs significantly within varieties [2] and not all varieties change their peel color during ripening [42]. Moreover, the external color of the fruits can vary because of external factors such as exposure to sunlight and harvesting time. In the Osteen $\mathrm{cv}$, fruits we found relevant peel and pulp color variations during both pre-harvest (Table 3) and post-harvest (Table 4) periods. When the on-tree growth rate of the fruit decreases, the most noticeable change in the fruit's color is the diminishment of the percentage of green, as confirmed by the shift of the parameter $\mathrm{a}^{*}$ towards the red frequencies $\left(+\mathrm{a}^{*}\right)$, due to an increase in the carotenoids content [3], responsible for the chromatic change of the peel of the fruit towards red-orange tone. We observed a significant variation in the values of $\mathrm{a}^{*}$ from 4.1 to 13.2 .

Table 3. Peel and pulp color of Osteen mango (mean $\pm \mathrm{SD}, n=12$ ) at harvest date (days after full flowering). L indicates the color's brightness, $a^{*}$ its position between red/magenta and green and $b^{*}$ its position between yellow and blue.

\begin{tabular}{|c|c|c|c|c|c|c|c|c|c|c|c|c|c|c|c|c|c|c|c|}
\hline \multirow{2}{*}{$\begin{array}{c}\begin{array}{c}\text { Harvest } \\
\text { Date }\end{array} \\
105\end{array}$} & \multicolumn{3}{|c|}{ L Peel } & \multicolumn{3}{|c|}{$a^{*}$ Peel } & \multicolumn{3}{|c|}{$b^{*}$ Peel } & \multicolumn{3}{|c|}{ L Pulp } & \multicolumn{4}{|c|}{$a^{*}$ Pulp } & \multicolumn{3}{|c|}{$b^{*}$ Pulp } \\
\hline & 40.5 & \pm 1.0 & ns & 4.1 & \pm 1.7 & $\mathrm{~b}$ & 15.7 & \pm 1.8 & $\mathrm{~b}$ & 77.1 & \pm 0.8 & ns & -11.9 & \pm & 0.4 & $\mathrm{e}$ & 30.3 & \pm 1.1 & $\mathrm{~d}$ \\
\hline 112 & 41.3 & \pm 1.2 & ns & 6.2 & \pm 2.0 & $a b$ & 16.3 & \pm 2.0 & $\mathrm{~b}$ & 78.3 & \pm 0.9 & . & -9.9 & + & 0.5 & $\mathrm{~d}$ & 31.4 & \pm 1.4 & $\mathrm{~d}$ \\
\hline 119 & 41.4 & \pm 1.2 & ns & 8.3 & \pm 1.8 & $a b$ & 13.4 & \pm 1.9 & $\mathrm{~b}$ & 79.0 & \pm 0.9 & & -7.8 & \pm & 0.5 & $\mathrm{C}$ & 36.4 & \pm 1.5 & $\mathrm{~cd}$ \\
\hline 126 & 40.0 & \pm 1.2 & ns & 11.0 & \pm 2.0 & $a b$ & 12.4 & \pm 1.9 & $\mathrm{~b}$ & 80.4 & \pm 0.9 & ns & -7.6 & \pm & 0.5 & $\mathrm{~cd}$ & 42.2 & \pm 1.4 & bc \\
\hline 133 & 41.1 & \pm 1.1 & ns & 9.9 & \pm 2.1 & $a b$ & 15.0 & \pm 1.7 & $\mathrm{~b}$ & 80.5 & \pm 0.8 & ns & -5.5 & \pm & 0.5 & bc & 39.2 & \pm 1.3 & $\mathrm{C}$ \\
\hline 140 & 38.1 & \pm 1.2 & ns & 11.7 & \pm 1.9 & $a b$ & 12.8 & \pm 1.9 & $\mathrm{~b}$ & 78.9 & \pm 0.9 & ns & -4.5 & \pm & 0.5 & bc & 48.0 & \pm 1.4 & bc \\
\hline 147 & 41.5 & \pm 1.2 & ns & 11.7 & \pm 2.1 & $a b$ & 17.4 & \pm 1.9 & $a b$ & 78.5 & \pm 0.9 & & -4.2 & \pm & 0.6 & $\mathrm{~b}$ & 48.7 & \pm 1.5 & $a b$ \\
\hline 154 & 41.7 & \pm 1.2 & ns & 10.0 & \pm 2.2 & $a b$ & 19.3 & \pm 1.9 & $\mathrm{a}$ & 80.4 & \pm 0.9 & ns & -4.6 & \pm & 0.5 & bc & 47.2 & \pm 1.4 & $a b$ \\
\hline 161 & 44.0 & \pm 1.2 & ns & 11.6 & \pm 1.9 & $a b$ & 23.4 & \pm 1.9 & $\mathrm{a}$ & 77.0 & \pm 1.0 & ns & -2.6 & \pm & 0.5 & $a b$ & 48.8 & \pm 1.4 & $\mathrm{a}$ \\
\hline 168 & 43.1 & \pm 1.2 & ns & 13.2 & \pm 2.2 & $\mathrm{a}$ & 20.2 & \pm 1.9 & $\mathrm{a}$ & 77.8 & \pm 0.9 & ns & -1.8 & \pm & 0.6 & $\mathrm{a}$ & 50.9 & \pm 1.8 & $\mathrm{a}$ \\
\hline
\end{tabular}

The values followed by different letters in the same column indicate significant differences $(p \leq 0.05)$.

Table 4. Peel and pulp color of Osteen mango (mean $\pm \mathrm{SD}, n=12$ ) at consumption point after storage period at $20{ }^{\circ} \mathrm{C}$ and $70 \% \mathrm{RH}$ (harvest date + shelf life). L indicates the color's brightness, $\mathrm{a}^{*}$ its position between red/magenta and green and $b^{*}$ its position between yellow and blue.

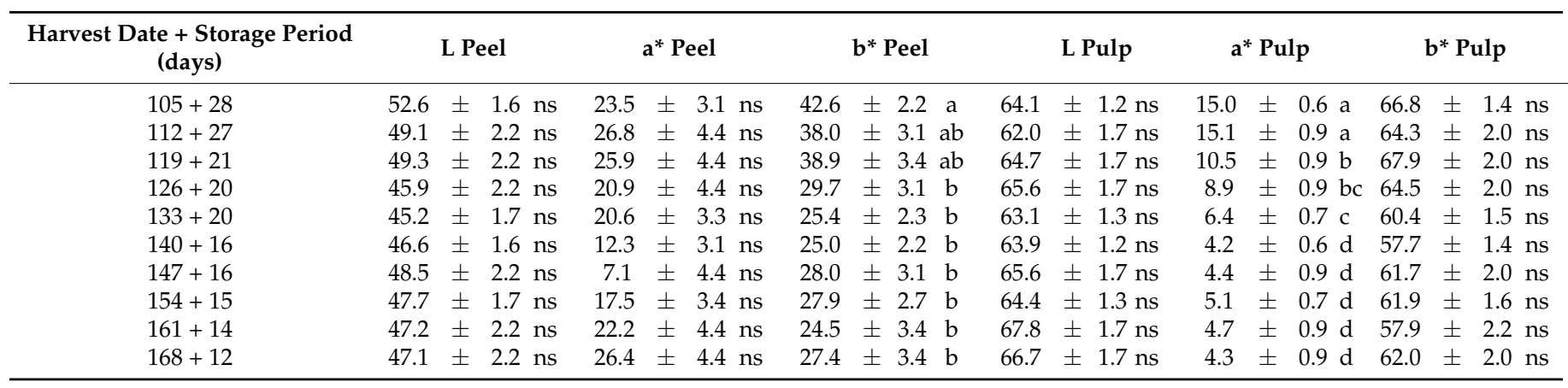

The values followed by different letters in the same column indicate significant differences $(p \leq 0.05)$.

Many consumers prefer mangos with a change of color in their peel because they link it to the characteristic taste and flavor of the well-ripe fruit [43]. The parameters $\mathrm{L}^{*}$ and $\mathrm{b}^{*}$ do not show substantial changes during this phase. During the growth phase, pulp a* and $\mathrm{b}^{*}$ parameters also undergo a variation, increasing their values linearly towards yellow $\left(+b^{*}\right)$ and red $\left(+a^{*}\right)$ tones. The color of the pulp went from a bright yellow to a more orange tone in the late-harvested fruits (in particular $\mathrm{a}^{*}$ values go from -11.9 to -1.8 and $\mathrm{b}^{*}$ values go from 30.3 to 50.9). During the fruit's ripening, it is possible to notice a diminishment in 
the brightness $\left(\mathrm{L}^{*}\right)$ and an increase, compared to the harvesting moment, in the parameters $a^{*}$ and $b^{*}$ of the fruit's peel, consumption point gains its typical orange to red color, which makes the fruit more appealing to the consumers [8]. On the other hand, the fruit's pulp shows a notable variation in its values for the parameter $\mathrm{a}^{*}$, which decrease from 15.0 to 4.3 until the consumption point is reached.

The sensory analysis was carried out when the fruits reached the consumption point (50-60 Durofel). The fruits harvested earliest (105 and 112 days from full flowering) had worse scores than those left on the tree longer. This can be explained by the lower TSSC $\left(<12^{\circ}\right.$ brix $)$ and DM $(<12 \%)$ values of these samples at consumption point, due to an abnormal or uneven ripening. On the other hand, $80 \%$ of the panelists evaluated as "very good" or "excellent" (with ratings higher than 8.5 out of 10.0) all the fruits tested in the different harvesting moments later than day 119 from full flowering.

The destructive analysis, which was performed in the harvested fruits every 7 days starting after 105 days from full flowering (earliest record of commercial maturity on the fruits), showed, as expected, an increase in TSS content from 6.8 at the beginning to $9.7^{\circ}$ Brix at the end of the harvest period; this was due to the approaching of the fruit to the full maturity (Table 5). Thus, it is possible to state that a longer stay on the tree leads to an exponential growth of the TSS content, even in the span of few weeks. Furthermore, De Lucena et al. [42] found an increase in the TSS content in Tommy Atkins cv. fruits from $5.6^{\circ}$ Brix on day 35 from anthesis to $8.5^{\circ}$ Brix on day 112 while Lederman et al. [44] pointed out an increase in the same variety from $7.5^{\circ}$ Brix on day 95 from full flowering to 10.9 on day 125. The TSS content is one of the parameters of greatest interest in the ripening process, as a sweeter fruit is more appealing to consumers [45]. The analyzed data show how the ${ }^{\circ}$ brix increases linearly in the fruits which are left on the tree, reaching at full maturity a value of $10.0^{\circ}$ brix. The fruits harvested on the same day reach values of $18^{\circ}$ brix at the consumption point after they were stored for a period of $20{ }^{\circ} \mathrm{C}$. The length of the storage period varies according to the harvest date (Figure 2). The fruits harvested on day 105 from full flowering showed an average TSS content value of $6.8^{\circ}$ brix at harvest and an average value of around $10^{\circ}$ brix after a storage period of 28 days at $20{ }^{\circ} \mathrm{C}$. Instead, as was mentioned before, fruits that were harvested later needed a shorter time to achieve an even higher increase in TSS content. Correlating the fruit's dimensional growth parameters and its physicochemical quality at harvest has an important practical value because growers can quantify the best moment for harvesting with the product's commercial use without needing to perform destructive analyses. The determination of the exact number of post-harvest $20^{\circ} \mathrm{C}$ storage days, based on the fruit's non-destructive quality parameters after harvest, such as hardness, can lead to important indications for optimal placement of the fruits on the market and can be used as an index of quality in other cultivars.

The titratable acidity, expressed as percentage of citric acid, varies according to the ripeness degree at the harvest moment and plays an important role in the final taste and flavor of the fruit, which are strongly influenced by its sugar/acid ratio [41]. In particular, the samplings carried out in our experiment showed that TA decreases from $1.12 \%$ on day 105 from full flowering to $0.35 \%$ on day 168 , while at consumption point significant differences were not observed $(0.11 \% \pm 0.01)$ within the samples. Therefore, this parameter undergoes a drastic reduction during the ripening process, as observed by Wongmetha [46], as the citric, ascorbic and malic acids are used as a substrate for the fruit respiratory processes [47]. The same author pointed out the slight increase in the $\mathrm{pH}$ values during the fruit development that was also observed in our study (from 3.49 to 3.93 at different harvest dates). For all harvest dates, at consumption point, $\mathrm{pH}$ values were higher than at harvest. 


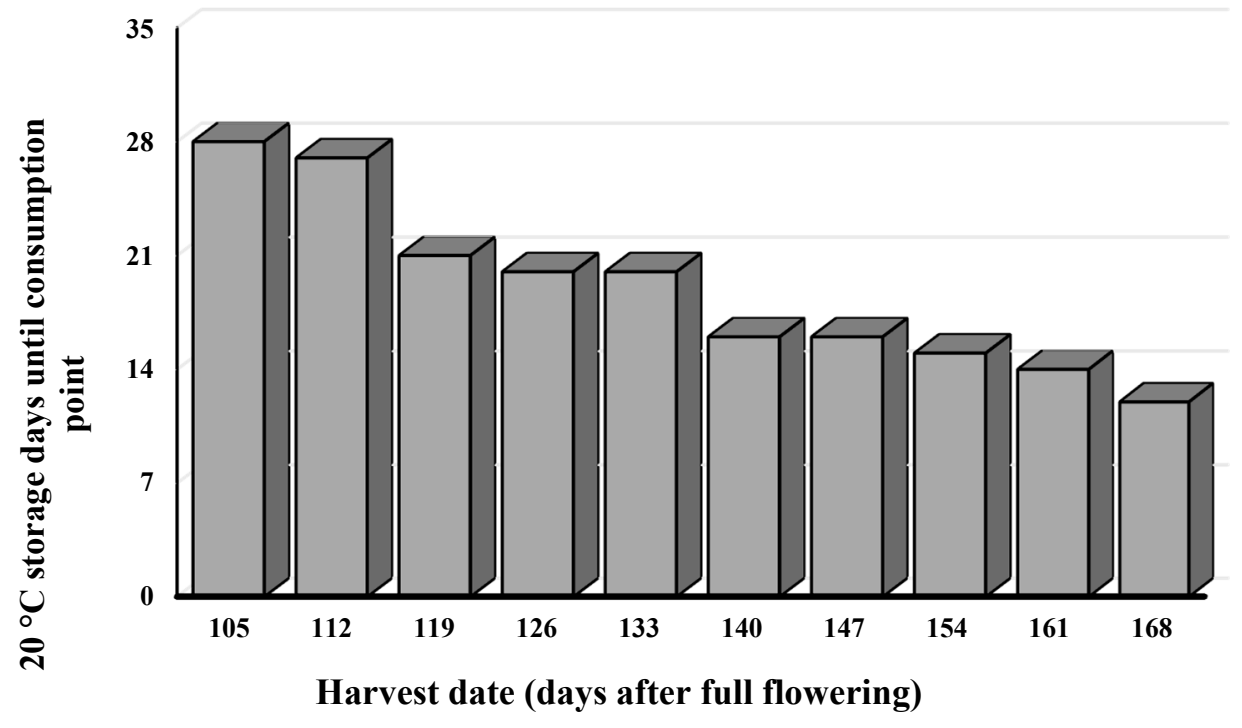

Figure 2. Number of storage days at $20^{\circ} \mathrm{C}$ until fruit reaches consumption point in relation to the harvesting moment (expressed in days from full flowering).

Table 5. Evolution of pH, Titratable Acidity (TA) and Total solids soluble content (TSS) at harvest (days from full bloom) and at consumption point.

\begin{tabular}{|c|c|c|c|c|c|c|c|}
\hline \multirow{2}{*}{$\begin{array}{l}\text { Harvest } \\
\text { Date }\end{array}$} & \multicolumn{3}{|c|}{ At Harvest } & \multirow{2}{*}{$\begin{array}{c}\text { Harvest Date + } \\
\text { Storage Period (Days) }\end{array}$} & \multicolumn{3}{|c|}{ At Consumption Point } \\
\hline & $\mathrm{pH}$ & TA & $\begin{array}{l}\text { TSS } \\
{ }^{\circ} \text { Brix }\end{array}$ & & $\mathrm{pH}$ & TA & $\begin{array}{l}\text { TSS } \\
{ }^{\circ} \text { Brix }\end{array}$ \\
\hline 105 & $3.49 \pm 0.02 c$ & $1.12 \pm 0.03 \mathrm{a}$ & $6.80 \pm 0.17 \mathrm{~d}$ & $105+28$ & $5.23 \pm 0.05 a$ & $0.08 \pm 0.00 \mathrm{~ns}$ & $10.43 \pm 0.36 \mathrm{f}$ \\
\hline 112 & $3.42 \pm 0.03 c$ & $1.07 \pm 0.06 \mathrm{a}$ & $6.98 \pm 0.20 \mathrm{~cd}$ & $112+27$ & $5.20 \pm 0.02 \mathrm{a}$ & $0.09 \pm 0.00 \mathrm{~ns}$ & $11.72 \pm 0.51 \mathrm{ef}$ \\
\hline 119 & $3.74 \pm 0.07 b$ & $0.85 \pm 0.04 b$ & $6.93 \pm 0.20 \mathrm{~cd}$ & $119+21$ & $5.19 \pm 0.07 \mathrm{a}$ & $0.07 \pm 0.01 \mathrm{~ns}$ & $13.11 \pm 0.51 \mathrm{de}$ \\
\hline 126 & $3.61 \pm 0.03 b$ & $0.76 \pm 0.02 b$ & $7.20 \pm 0.29 c$ & $126+20$ & $4.58 \pm 0.03 c$ & $0.12 \pm 0.00 \mathrm{~ns}$ & $13.43 \pm 0.51 \mathrm{~d}$ \\
\hline 133 & $3.74 \pm 0.01 b$ & $0.59 \pm 0.09 c$ & $7.68 \pm 0.18 b c$ & $133+20$ & $5.10 \pm 0.16 \mathrm{a}$ & $0.11 \pm 0.03 \mathrm{~ns}$ & $14.85 \pm 0.45 c$ \\
\hline 140 & $3.76 \pm 0.02 b$ & $0.55 \pm 0.03 c$ & $8.18 \pm 0.20 b$ & $140+16$ & $4.93 \pm 0.06 \mathrm{ab}$ & $0.12 \pm 0.01 \mathrm{~ns}$ & $15.14 \pm 0.40 c$ \\
\hline 147 & $3.88 \pm 0.08 \mathrm{a}$ & $0.52 \pm 0.06 c$ & $9.30 \pm 0.20 \mathrm{a}$ & $147+16$ & $4.75 \pm 0.07 \mathrm{~b}$ & $0.15 \pm 0.04 \mathrm{~ns}$ & $13.70 \pm 0.51 c$ \\
\hline 154 & $3.91 \pm 0.02 \mathrm{a}$ & $0.48 \pm 0.06 c$ & $9.35 \pm 0.25 \mathrm{a}$ & $154+15$ & $4.88 \pm 0.09 \mathrm{ab}$ & $0.13 \pm 0.01 \mathrm{~ns}$ & $15.96 \pm 0.40 \mathrm{ab}$ \\
\hline 161 & $3.97 \pm 0.04 \mathrm{a}$ & $0.37 \pm 0.04 \mathrm{~d}$ & $9.37 \pm 0.29 \mathrm{a}$ & $161+14$ & $4.95 \pm 0.05 \mathrm{ab}$ & $0.12 \pm 0.01 \mathrm{~ns}$ & $15.72 \pm 0.51 b$ \\
\hline 168 & $3.94 \pm 0.05 \mathrm{a}$ & $0.33 \pm 0.02 \mathrm{~d}$ & $9.73 \pm 0.20 \mathrm{a}$ & $168+12$ & $4.92 \pm 0.04 \mathrm{ab}$ & $0.14 \pm 0.02 \mathrm{~ns}$ & $17.50 \pm 0.51 \mathrm{a}$ \\
\hline
\end{tabular}

The values followed by different letters in the same column indicate significant differences (Tukey test, $p<0.05 ; \mathrm{ns}=$ not significant).

\section{Conclusions}

The qualitative characteristics of mango, cv. Osteen, fruits varied throughout their development process even after the fruits reached their final dimensions, in relation to the length of their stay on the plant and also to their post-harvest management. The study showed that mango fruits that are kept on the tree reach the best quality traits, corresponding to their physiological maturation. In fact, the length of the storage period needed to reach the consumption point varies greatly according to the harvesting moment and to the different environmental parameters, which also affect the organoleptic and physicochemical quality of the fruits.

The analysis highlighted how the firmness and consistency of the fruits at harvest stay similar regardless of the harvest date, but they decrease with different speeds, in relation to the harvest date, after a period of storage (Figure 3). However, the panel test judges did not highlight noticeable differences in the fruits that had been harvested 119 days after full flowering and onwards which were then evaluated at the consumption point. Detecting a precise harvesting time is of the utmost importance, as this strongly affects the fruit's further maturation process and its subsequent shelf-life. 


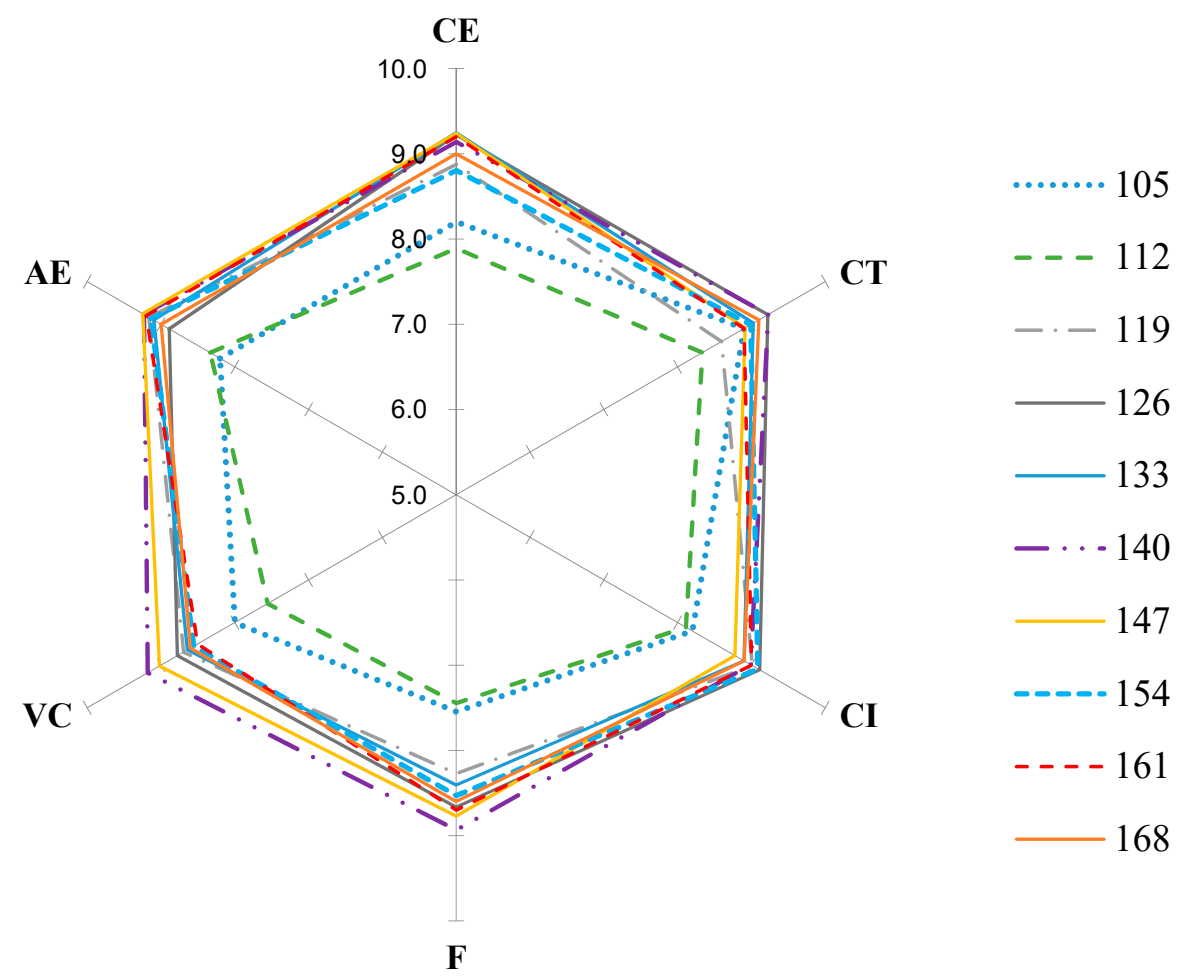

Figure 3. Sensory profile at consumption point, in relation to the harvest date (Days from full flowering). $\mathrm{CE}=$ Peel color; $\mathrm{CT}=$ Tactile firmness; $\mathrm{CI}=$ Pulp color; $\mathrm{F}=$ Flavor; $\mathrm{VC}=$ Overall evaluation; $\mathrm{AE}=$ Overall appearance.

The data collected in this study confirm that the number of days from full flowering, that is the length of the fruit's stay on the tree, is primary information to consider when deciding the harvest moment of the fruit, depending on its planned commercial use. Our results showed that from 126 to 133 days from full flowering there was a more noticeable consumer acceptability. This corresponds to higher DM values of $14-15 \%$.

This information on the fruit's behavior based on its harvest date can, therefore, help improve the product's post-harvest management practices, to provide a product with constant quality and homogeneity to the consumer.

Author Contributions: Conceptualization, M.G.L.R. and G.G.; methodology, G.G. and M.G.L.R.; validation, M.G.L.R., V.F. and P.I.; formal analysis, M.G.L.R., G.G., V.F. and, P.I.; investigation, G.G.; data curation, G.G.; writing—original draft preparation, G.G.; writing—review and editing, M.G.L.R., V.F., P.I. and G.G.; supervision, M.G.L.R., V.F. and P.I. All authors contributed to the writing of the paper. All authors have read and agreed to the published version of the manuscript.

Funding: This research received no external funding.

Institutional Review Board Statement: Not applicable.

Informed Consent Statement: Not applicable.

Data Availability Statement: The data presented in this study are available on request from the corresponding author.

Conflicts of Interest: The authors declare no conflict of interest.

\section{References}

1. Fukuda, S.; Yasunaga, E.; Nagle, M.; Yuge, K.; Sardsud, V.; Spreer, W.; Müller, J. Modelling the relationship between peel colour and the quality of fresh mango fruit using Random Forests. J. Food Eng. 2014, 131, 7-17. [CrossRef]

2. Sivakumar, D.; Jiang, Y.; Yahia, E.M. Maintaining mango (Mangifera indica L.) fruit quality during the export chain. Food Res. Int. 2011, 44, 1254-1263. [CrossRef] 
3. Baloch, M.K.; Bibi, F. Effect of harvesting and storage conditions on the postharvest quality and shelf life of mango (Mangifera indica L.) fruit. S. Afr. J. Bot. 2012, 83, 109-116. [CrossRef]

4. Kader, A.A. Mango Quality Attributes and Grade Standards: A Review of Available Information and Identification of Future Research Needs (Report to the National Mango Board); Kader Consulting Services: Davis, CA, USA, 2008.

5. Jacobi, K.K.; Wong, L.S.; Giles, J.E. Effect of fruit maturity on quality and physiology of high-humidity hot air-treated 'Kensington'mango (Mangifera indica Linn.). Postharvest Biol. Technol. 1995, 5, 149-159. [CrossRef]

6. Lalel, H.J.D.; Singh, Z.; Tan, S.C. Distribution of aroma volatile compounds in different parts of mango fruit. J. Hortic. Sci. Biotechnol. 2003, 78, 131-138. [CrossRef]

7. Nunes, M.C.N.; Emond, J.P.; Brecht, J.K.; Dea, S.; Proulx, E. Quality curves for mango fruit (cv. Tommy Atkins and Palmer) stored at chilling and nonchilling temperatures. J. Food Qual. 2007, 30, 104-120. [CrossRef]

8. Galán Sauco, V.; Lu, P. Achieving Sustainable Cultivation of Mangoes; Burleigh Dodds Science Publishing Limited: Cambridge, UK, 2018.

9. Tandon, D.K.; Kalra, S.K.; Singh, B.P. Ripening pattern of specific gravity graded 'Dasheri' mangoes. Indian J. Hort. 1986, 45, 219-223.

10. Ueda, M.; Sasaki, K.; Utsunomiya, N.; Inaba, K.; Shimabayashi, Y. Effect of temperature and time on some properties during storage of mango fruit (Mangifera indica L. 'Irwin') cultured in plastic house. J. Jpn. Soc. Food Sci. Technol. 2001, 48, 349-355. [CrossRef]

11. Gowda, I.N.D.; Huddar, A.G. Studies on ripening changes in mango (Mangifera indica L.) fruits. J. Food Technol. 2001, 38, 135-137.

12. Gentile, C.; Mannino, G.; Palazzolo, E.; Gianguzzi, G.; Perrone, A.; Serio, G.; Farina, V. Pomological, Sensorial, Nutritional and Nutraceutical Profile of Seven Cultivars of Cherimoya (Annona cherimola Mill). Foods 2021, 10, 35. [CrossRef]

13. Galán Saúco, V.; Hormaza, I. Tropical Fruit Crops in Spain and Portugal. Chron. Hortic. Subscr. 2001, 49, $24-25$.

14. Medlicott, A.P.; Jeger, M.J. Mangoes-A Review, 56-77. In the Development and Application of Post-Harvest Treatments to Manipulate Ripening in Mangoes; Prinsley, R.T., Tucker, G., Eds.; Commonwealth Science Council: London, UK, 1987.

15. Herold, B.; Truppel, I.; Zude, M.; Geyer, M. Spectral measurements on 'Elstar' apples during fruit development on the tree. Biosyst. Eng. 2005, 91, 173-182. [CrossRef]

16. Yahia, E.M. Postharvest Handling of Mangoes. Technical Report; Agricultural Technology Utilization and Transfer Project: Giza, Egypt, 1998.

17. Souza, J.M.A.; Leonel, S.; Modesto, J.H.; Ferraz, R.A.; Gonçalves, B.H.L. Phenological cycles, thermal time and growth curves of mango fruit cultivars in subtropical conditions. Br. J. Appl. Sci. Technol. 2015, 9, 100-107. [CrossRef]

18. Kienzle, S.; Sruamsiri, P.; Carle, R.; Sirisakulwat, S.; Spreer, W.; Neidhart, S. Harvest maturity specification for mango fruit (Mangifera indica L.'Chok Anan') in regard to long supply chains. Postharvest Biol. Technol. 2011, 61, 41-55. [CrossRef]

19. Jha, S.N.; Kingsly, A.R.P.; Chopra, S. Physical and mechanical properties of mango during growth and storage for determination of maturity. J. Food Eng. 2006, 72, 73-76. [CrossRef]

20. Jha, S.N.; Narsaiah, K.; Shar-ma, A.D.; Singh, M.; Bansal, S.; Kumar, R. Quality parameters of mango and potential of nondestructive techniques for their measurement-A review. J. Food Sci. Technol. 2010, 47, 1-14. [CrossRef]

21. Farina, V.; Passafiume, R.; Tinebra, I.; Scuderi, D.; Saletta, F.; Gugliuzza, G.; Gallotta, A.; Sortino, G. Postharvest application of aloe vera gel-based edible coating to improve the quality and storage stability of fresh-cut papaya. J. Food Qual. 2020, 2020, 1-10. [CrossRef]

22. Makani, O.A. Mango Quality Survey and Sensory Evaluation of Mango (Mangifera indica L.) Cultivars; University of Queensland: Brisbane, Australia, 2009.

23. Koppen, W. Das geographische system der klimat. In Handbuch der klimatologie; Gebrüder Borntraeger: Berlin, Germany, $1936 ;$ p. 46.

24. Papadakis, J. Climates of the World and Their Agricultural Potentialities; J. Papadakis: Buenos Aires, Argentina, 1966.

25. Hernández Delgado, P.M.; Aranguren, M.; Reig, C.; Galvan, D.F.; Mesejo, C.; Fuentes, A.M.; Agusti, M. Phenological growth stages of mango (Mangifera indica L.) according to the BBCH scale. Sci. Hortic. 2011, 130, 536-540. [CrossRef]

26. Larmond, E. Métodos de Laboratorio Para la Evaluación Sensorial de Alimentos. Res. Branch Can. Dep. Agric. Publ. 1977, $1637,77$.

27. Vangdal, E.; Flatland, S.; Lunde Knutsen, I.; Larsen, H. Factors affecting storability and shelf life in plums (Prunus domestica L.). Acta Hortic. 2010, 968, 197-203. [CrossRef]

28. Farina, V.; Barone, F.; Mazzaglia, A.; Lanza, C.M. Evaluation of fruit quality in loquat using both chemical and sensory analyses. Acta Hortic. 2011, 887, 345-349. [CrossRef]

29. Litz, R.E. (Ed.) The Mango: Botany, Production and Uses; Cabi: Wallingford, UK, 2009.

30. Davenport, T.L. Reproductive Physiology. The Mango: Botany Production and Uses; CAB International: Wallingford, UK, 2009; pp. 97-169.

31. Zaharah, S.S.; Singh, Z.; Symons, G.M.; Reid, J.B. Mode of action of abscisic acid in triggering ethylene biosynthesis and softening during ripening in mango fruit. Postharvest Boil. Technol. 2013, 75, 37-44. [CrossRef]

32. Fuchs, Y.; Pesis, E.; Zauberman, G. Changes in amylase activity, starch and sugars contents in mango fruit pulp. Sci. Hortic. 1980, 13, 155-160. [CrossRef]

33. Liguori, G.; Gentile, C.; Sortino, G.; Inglese, P.; Farina, V. Food quality, sensory attributes and nutraceutical value of fresh "Osteen" mango fruit grown under mediterranean subtropical climate compared to imported fruit. Agriculture 2020, 10, 103. [CrossRef]

34. Schouten, R.E.; Fan, S.; Verdonk, J.C.; Wang, Y.; Kasim, N.F.M.; Woltering, E.J.; Tijskens, L.M.M. Mango firmness modeling as affected by transport and ethylene treatments. Front. Plant Sci. 2018, 9, 6-16. [CrossRef] 
35. Fishman, S.; Génard, M. A biophysical model of fruit growth: Simulation of seasonal and diurnal dynamics of mass. Plant Cell Environ. 1998, 21, 739-752. [CrossRef]

36. Castro Neto, M.T.D.; Reinhardt, D.H. Relationship between fruit growth parameters of mango cv. Haden. Rev. Bras. Frutic. 2003, 25, 35-37. [CrossRef]

37. Walsh, K.; Wang, Z. Monitoring Fruit Quality and Quantity in Mangoes in Gàlan Saùco, V., Lu, P. Achieving Sustainable Cultivation of Mangoes; Burleigh Dodds Science Publishing: Cambridge, UK, 2018.

38. Hofman, P.J.; Smith, L.G.; Joyce, D.C.; Johnson, G.I.; Meiburg, G.F. Bagging of mango (Mangifera indica cv. Keitt') fruit influences fruit quality and mineral composition. Postharvest Biol. Technol. 1997, 12, 83-91. [CrossRef]

39. Diczbalis, Y.; Hofman, P.; Landrigan, M.; Kulkarni, V.; Smith, L. Mango Irrigation Management for Fruit Yield, Maturity and Quality. In Proceedings of the Mango 2000 Marketing Seminar and Production Workshop, Brisbane, Australia, 3 August 1995; pp. 85-90.

40. Penchaiya, P.; Tijskens, L.M.; Uthairatanakij, A.; Srilaong, V.; Tansakul, A.; Kanlayanarat, S. Modelling quality and maturity of 'Namdokmai Sithong' mango and their variation during storage. Postharvest Biol. Technol. 2020, 159, 1-11. [CrossRef]

41. Briceño, S.; Zambrano, J.; Materano, W.; Quintero, I.; Valera, A. Calidad de los frutos de mango bocado, madurados en la planta y fuera de la planta cosechados en madurez fisiológica. Agron. Trop. 2005, 55, 461-473.

42. De Lucena, E.M.P.; de Assis, J.S.; Alves, R.E.; da Silva, V.M.; Eneas Filho, J. Alterações Físicas e Químicas Durante o Desenvolvimento de Mangas Tommy Atkins no Vale do São Francisco, Petrolina-PE. Rev. Bras. Frutic. 2007, 29, 96-101. [CrossRef]

43. Subedi, P.P.; Walsh, K.B.; Owens, G. Prediction of mango eating quality at harvest using short-wave near infrared spectrometry. Postharvest Biol. Technol. 2007, 43, 326-334. [CrossRef]

44. Lederman, I.E.; Bezerra, J.E.F.; Carvalho, P.S.; De Alves, M.A.; Dos Santos, V.F. Determinação do ponto de colheita da manga cv. Tommy Atkins, para a região semiárida de Pernambuco. Rev. Bras. Frutic. 1998, 20, 145-151.

45. Quintero, V.; Giraldo, G.; Lucas, J.; Vasco, J. Caracterización fisicoquímica del mango común (Mangifera indica L.) durante su proceso de maduración. Biotecnol. Sect. Agropecu. Agroind. 2013, 11, 8-18.

46. Wongmetha, O.; Ke, L.S.; Liang, Y.S. The changes in physical, bio-chemical, physiological characteristics and enzyme activities of mango cv. Jinhwang during fruit growth and development. NJAS-Wagening. J. Life Sci. 2015, 72, 7-12. [CrossRef]

47. Jacobi, K.K.; MacRae, E.A.; Hetherington, S.E. Postharvest heat disinfestation treatments of mango fruit. Sci. Hortic. 2001, 89, 171-193. [CrossRef] 